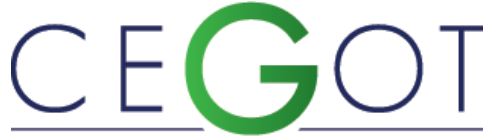

Centro de Estudos de Geografia e Ordenamento do Território
Graviola, Gabriela

UNESP - Universidade Estadual Paulista "Julio Mesquita

Filho", Campus Bauru

FAAC - Faculdade de Arquitetura, Artes e Comunicação

17033-360, Av. Eng. Luís Edmundo Carrijo Coube, 14-01 - Vargem Limpa, Bauru - SP, Brasil

gabriela.rosa@unesp.br

Constantino, Norma

UNESP - Universidade Estadual Paulista "Julio Mesquita

Filho", Campus Bauru.

FAAC - Faculdade de Arquitetura, Artes e Comunicação

17033-360, Av. Eng. Luís Edmundo Carrijo Coube, 14-01 - Vargem Limpa,

Bauru - SP, Brasil

nconst@faac.unesp.br

\title{
Percepção do Rio Tietê na paisagem urbana de Barra Bonita, Brasil
}

Perception of Tietê River in urban landscape in Barra Bonita, Brasil

Referência: Graviola, Gabriela; Constantino, Norma (2020). Percepção do Rio Tietê na paisagem urbana de Barra Bonita, Brasil Revista de Geografia e Ordenamento do Território (GOT), no 19 (junho). Centro de Estudos de Geografia e Ordenamento do Território, p. 106-131 dx.doi.org/10.17127/got/2020.19.005

\section{RESUMO}

Esse artigo se propõe a analisar como o Rio Tietê está inserido na paisagem urbana de Barra Bonita-SP, Brasil, considerando a percepção da população, a história e o contexto socioambiental. Primeiramente, foi feito um levantamento histórico da ocupação do Rio Tietê no Oeste paulista e da formação de Barra Bonita, além do levantamento do contexto socioambiental no qual o rio se insere. Em seguida, foram mapeadas as áreas fluviais da cidade e aplicados questionários à população. Analisando os resultados, observa-se que a população ainda mantém um forte vínculo afetivo com o rio, porém há muito a se fazer para explorar todo o potencial turístico da cidade, bem como aperfeiçoar a interação e a reconexão das pessoas com a paisagem fluvial.

Palavras-chave: Rios urbanos; Paisagem; Oeste Paulista; àguas fluviais; Cidade turística

\section{ABSTRACT:}

This article aims to analyse how the Tietê River is inserted in Barra Bonita's urban landscape, in Sao Paulo State-BR considering the population's perception, history and socioenvironmental context. First, we analysed the historical occupation of the Tietê River in the west of São Paulo and the foundation of the municipality of Barra Bonita. Then, we analysed the current socio environmental context and we made a land cover map of the river areas in the city. At least, we applied questionnaires about river's perception to the population. The result was that the people still has a strong affective bond with the river. However, there 
are many polices and environmental practices that must to be implemented to explore the full potential of the city and to improve people's interaction with the river landscape.

Keywords: Urban rivers; Landscape; West São Paulo state; Fluvial water; Tourism town

\section{Introdução}

A compreensão da percepção humana em relação aos rios na paisagem urbana é muito importante, pois a história da interação rio-cidade sempre mostrou que as cidades eram frequentemente construídas em torno das águas fluviais, uma vez que estas forneciam água potável, fertilidade para agricultura, peixes, caça e argila para produção de utensílios e ferramenta (Lerner; Holt, 2012). Grande parte das civilizações antigas surgiram em torno de rios (Faber, 2011), com os quais estabeleciam uma relação sagrada e de muito respeito (Nóbrega, 1978). Contudo, com o advento da Revolução Industrial, essa relação começou a mudar. Nesse período, as indústrias eram frequentemente instaladas ao longo de rios e córregos (Palmer; Neaverson, 1998) onde também eram despejados os dejetos e poluentes industriais os quais, em conjunto com a expansão urbana e o consequente despejo de efluentes domésticos, transformaram os rios em esgotos a céu aberto e fontes transmissoras de doenças. Como solução para eliminar esses focos de doenças, numa visão higienista, muitas cidades no mundo inteiro adotaram como medida principal a canalização dos rios (Herzog, 2013). Essa medida transformou o modo como o ser humano se relaciona com o rio. Diante desse contexto, esse artigo se propõe analisar a percepção que as pessoas têm do Rio Tietê na cidade de Barra Bonita-SP e compreender como o rio se insere na paisagem urbana, considerando os aspectos históricos e socioambientais. Para esse entendimento, porém, faz-se necessário compreender alguns conceitos sobre história, paisagem e percepção.

Para Benjamin (2012), história designa tanto o conjunto de todos os acontecimentos, quanto a narrativa, uma vez que a história é inseparável da atividade narrativa e das várias formas de narrar, sendo esta definida como "a faculdade de intercambiar experiências". A história tem relação com a memória, sob uma dimensão ética muito importante, pois consiste em preservá-la, em salvar o desaparecido, o passado, em resgatar tradições, vidas, falas e imagens (Rosa, 2016). Segundo Le Goff (1990, p.476), “a memória não é somente 
uma conquista, é também um instrumento e um objeto de poder, na medida em que, pela dominação da recordação e da tradição, o grupo se afirma e se reconhece".

Sob essa perspectiva histórica e de memória, é possível compreender e resgatar a relação que as cidades e seus habitantes estabeleceram e vêm estabelecendo com os rios na paisagem urbana, ao longo do tempo. A paisagem é uma palavra que tem múltiplos significados. Besse (2014) sintetiza essas categorias em cinco formas principais de se conceber a paisagem: 1) representação cultural e social; 2) território produzido pelas sociedades ao longo da história; 3) complexo sistêmico; 4) projeto; e 5) espaço de uma experiência fenomenológica. Essa última está atrelada à percepção do indivíduo que, na concepção fenomenológica, apresentada por Merleau-Ponty (1994), trata-se da apreensão de sentidos pelo corpo, a partir da experiência do indivíduo que olha, sente e reconhece o espaço como expressivo e simbólico. A abordagem fenomenológica é capaz de articular as condições sócio-históricas, subjetivas e cognitivas para o conhecimento (Nóbrega, 2008).

Nesse sentido, é possível perceber a paisagem como o conjunto de tudo isso, conciliando tanto os aspectos físicos, sociais e históricos, quanto àqueles ideológicos e psicológicos. Meinig (1979) sintetiza essa ideia, dizendo que "qualquer paisagem é composta não apenas pelo que está diante de nossos olhos, mas também pelo o que está dentro de nossas cabeças". As paisagens são parte da nossa vida cotidiana e estão presentes tanto no plano individual (nosso ser), quanto no plano coletivo (nossa vida) (Besse, 2013). Não se trata de apenas uma vista, mas elas compreendem um mundo vivido, fabricado ou habitado por sociedades humanas em constante mudança (Besse, 2014).

Assim sendo, a interação rio-cidade é uma interessante relação a ser analisada do ponto de vista de paisagem, pois agrega meios naturais, culturais e históricos. Compreender esta relação, porém, não é apenas observar seus aspectos físicos, mas sim compreender o significado do rio ao longo da história. Para isso, é necessário ativar a memória do local e das pessoas que nele se inserem. Além disso, é essencial sua ressignificação na cidade para que as águas fluviais sejam novamente tratadas como um recurso complexo, capaz de gerar bem-estar e diversos serviços ambientais na cidade (Magnaghi; Giacomozzi, 2009). Como Anelli (2015) cita: "a coexistência entre áreas urbanizadas e as águas é um desafio de grandes proporções, que vem sendo discutido de modo cada vez mais intenso". Desse 
modo, esse artigo $^{1}$ se propõe analisar como o Rio Tietê se encontra inserido na paisagem urbana de Barra Bonita, considerando os aspectos históricos e socioambientais. Os objetivos específicos são: (a) levantamento histórico da relação de Barra Bonita e o Rio Tietê; (b) análise da área fluvial e o uso e ocupação do solo de Barra Bonita, considerando os aspectos socioambientais; e (c) levantamento da percepção da população em relação ao Rio.

\section{Material e Métodos}

Primeiramente, foi realizado o levantamento histórico de Barra Bonita, com base em literatura pertinente ao tema. Foram utilizadas fontes textuais, iconográficas e cartográficas. O recorte temporal nesse caso começou em 1877, ano em que ocorreu a monção exploradora e povoadora do Rio Tietê que deu origem a cidade. A partir desse ponto, foi levantado o histórico da relação rio-cidade até a atualidade. Para isso, foi usado o conceito amplo de documentos, considerado aqui, como "um produto da sociedade que o fabricou" (Le Goff, 1990, p. 545). Portanto, foram utilizadas reportagens, notícias de jornais, documentos de cartório, teses, artigos e livros que abordam a história da relação do rio com a cidade. Foram utilizados, também, mapas, desenhos e fotografias que serviram para complementar as informações colhidas nas fontes textuais. Como explicado por Carvalho e Wolff (2008), as fotografias são documentos úteis para comprovação de relatórios, revelação do uso de determinado local, registros de eventos, entre outros.

Para a compreensão do contexto socioambiental em que o rio se insere na cidade, foi usada uma ampla gama de documentos. O recorte temporal abrangeu tudo aquilo que ainda se faz presente na atualidade (até os últimos cinco anos): leis vigentes; atuais planos diretores; e projetos e informações sobre a realidade das cidades, nos seus múltiplos aspectos ambiental e econômico. Foi utilizado o levantamento mais recente do IBGE e do município e foram consultadas as leis relacionadas à Área de Preservação Permanente - APP urbana,

\footnotetext{
${ }^{1}$ Este artigo baseia-se parcialmente no conteúdo apresentado na dissertação de Mestrado em Arquitetura e Urbanismo da autora, intitulada "Percepção, história e ressignificação do Rio Tietê no Oeste paulista: os casos de Barra Bonita e Pederneiras", a ser concluída em 2020 no Programa de Pós-Graduação em Arquitetura e Urbanismo, da Universidade Estadual Paulista (PPGARQ-UNESP), Bauru-SP, Brasil. Uma versão prévia e incompleta desse artigo foi publicado como resumo expandido ao título de "Os rios no contexto da paisagem urbana: o caso de Barra Bonita" nos anais do V Encontro da Associação Nacional de Pesquisa e PósGraduação em Arquitetura e Urbanismo, que ocorreu em Salvador, 2018.
} 
mata ciliar (CONAMA), e às águas (Código das Águas) no âmbito federal, estadual e municipal. As teses utilizadas nessa etapa foram aquelas que tratam da qualidade da água (Buzelli e Cunha-Santino, 2013), qualidade do ar e do solo, geomorfologia e pedologia. Nesse caso, o interesse aqui foi, objetivamente, encontrar as características físicas e políticas de Barra Bonita. Também foram considerados aspectos como a participação da cidade no programa Município Verde Azul, da Secretaria do Meio Ambiente do Estado de São Paulo.

Em relação aos documentos icnográficos, foram realizadas visitas de campo para registrar, por meio de fotografia e anotações, as margens do Rio Tietê e seu entorno. Os materiais icnográficos e cartográficos serviram para a descrição física da paisagem e, também, para registrar se há presença de parque linear, erosão, moradias irregulares, bem como constatar se as áreas em torno dos rios estão de acordo com a legislação. Além disso, foram mapeadas as coberturas de solos principais, a partir de imagens de satélites fornecidas pelo geocatálogo online, com o uso do Sistema de Informação Geográfica (software ArcGis).

Para elaborar os mapas, obtivemos imagens do satélite RapidEye de $25 \mathrm{~km}^{2}$, do ano de 2015, com resolução espacial de $5 \mathrm{~m}$ e com 5 bandas espectrais, cobrindo o território de Barra Bonita, no catálogo on-line do Ministério do Meio Ambiente do Brasil (http://geocatalogo.mma.gov.br/). Em seguida, foi realizada uma classificação supervisionada automática gerada pelo ArcGIS. Nesse tipo de classificação é necessário utilizar áreas de treinamento (training sites) para os principais tipos de cobertura vegetal e uso das terras da região de interesse. Essas áreas de treinamento são utilizadas para que o software realize a classificação de cada pixel da imagem (Magnani, 2015). No presente estudo, os training sites foram amostras de quatro classes principais de uso de solo: área urbana, água, vegetação arbórea e vegetação herbácea (incluindo agricultura, que é basicamente dominada pela plantação de cana-de-açúcar). Estabelecidos os training sites, a classificação do primeiro mapa de uso de solo foi definida por meio da ferramenta Maximum Likelihood Classifier do ArcGIS, onde todos os demais pixels da imagem são classificados com base na semelhança de suas firmas espectrais com as das áreas assinaladas (training sites).

Em seguida, foram elaborados questionários que continham perguntas estruturadas mistas entre abertas e fechadas. Para escolher o número de questionários necessários visando um 
tamanho amostral que representasse a população, utilizamos a calculadora do site Netquest ${ }^{2}$, utilizado em outros estudos (Foloni, 2018). Foram aplicados 270 questionários, dos quais 156 foram realizados presencialmente por meio de entrevistas com a população que caminhava nas ruas de Barra Bonita e 114 foram aplicados online por meio da ferramenta Google Formulários, sendo o link postado em grupos de Barra Bonita do Facebook. A escolha dos entrevistados foi aleatória, porém baseando-se na proporção do número de homens e mulheres e a faixa etária da população total, segundo a lógica do Systematic Design (Hurlbert, 1984).

Para a análise dos questionários, foram consideradas as características dos entrevistados: gênero, escolaridade e faixa etária; em seguida, foram analisadas as informações coletadas nas entrevistas tanto pelo viés quantitativo, quanto pelo qualitativo, pois os questionários apresentam perguntas abertas e fechadas. Depois foi verificado se há correlação entre cada variável (sexo, escolaridade e faixa etária) e as respostas. Em relação às perguntas abertas, o método utilizado foi o qualitativo, que "enfatiza as particularidades de um fenômeno em termos de seu significado para o grupo pesquisado" (Goldenberg, 2011, p.49). Logo, nessa etapa, as respostas foram transcritas e analisadas individualmente.

\section{Resultados}

\subsection{O Rio Tietê}

Conhecido também como Rio Grande, Anhembi, Inambuí e Piratininga, nos tempos mais remotos, o Rio Tietê nasce em Salesópolis, na Serra do Mar, no estado de São Paulo a 1120 metros de altitude e a $22 \mathrm{~km}$ do Oceano Atlântico e, diferentemente dos demais rios, corre no sentido inverso ao mar, percorrendo boa parte do interior paulista, onde deságua no rio Paraná, no município de Três Lagoas, Mato Grosso do Sul (Santiago, 2017). Ao todo, o rio tem 1150 km de extensão, percorre 62 municípios e é dividido em quatro partes principais:

\footnotetext{
${ }^{2}$ Essa ferramenta calcula o valor necessário de réplicas das amostras baseado no tamanho do universo (número total de pessoas em cada cidade), porcentagem de margem de erro (padrão estatístico = 5\%), nível de confiança (padrão estatístico $=95 \%$ ) e heterogeneidade. Para este último item, o valor a ser considerado foi de $50 \%$, que é o padrão universal de probabilidade quando se trata de gênero sexual. Ver mais em https://www.netquest.com
} 
o Alto Tietê (das nascentes à cidade de Pirapora do Bom Jesus); Médio Tietê superior (da cidade de Pirapora de Bom Jesus à cidade de Laras); Médio Tietê Inferior (da cidade de Laras à corredeira de Laje); e Baixo Tietê (da corredeira da Laje à foz no Rio Paraná) (Borges, 2017).

Situado ao longo dos biomas Mata Atlântica e Cerrado, o Rio Tietê sempre apresentou uma exuberante fauna e flora que foi relatada com detalhes por seus viajantes, como Xeria (1628), Juzarte (1769) e pela expedição da Comissão Geográfica do Estado de São Paulo (CGG, 1995) e tantos outros relatos de viajantes compilados por Nóbrega (1978). Atualmente, porém, muito pouco da vegetação nativa ainda existe. Segundo os dados do SOS Mata Atlântica, seu trecho mais preservado é aquele do Alto Tietê que apresenta 21\% do território coberto com remanescentes florestais da Mata Atlântica no território (Hirota; Ribeiro, 2016). Contudo, considerando o interior paulista, a situação se agrava, pois seu território é dominado pelas culturas intensivas de cana-de-açúcar que dizimou quase toda a vegetação nativa. Na porção do Médio Tietê, restam apenas $6 \%$ da vegetação nativa e, no trecho do Baixo-Tietê, a proporção cai para 3\% (Hirota; Ribeiro, 2016).

\subsection{As monções e o nascimento do território de Barra Bonita}

O Tietê, assim como outros rios brasileiros, foi encarado como via de penetração no interior do continente, tornando-se base de fixação dos povoamentos e limites políticos brasileiros (Correa, 2008). Muitas das principais cidades brasileiras foram fundadas próximas a corpos d'água, principalmente devido às necessidades materiais vitais: a água para beber e a coleta de alimentos ofertados pelas zonas ripárias (Mello, 2008). Considerando apenas o Estado de São Paulo, o Rio Tietê teve o papel central na história da ocupação e colonização do interior paulista, uma vez que este atravessa o Estado de leste a oeste (Correa, 2008). No livro História do Rio Tietê, Nóbrega (1978) reúne toda documentação existente sobre o rio até o ano de 1978 e percebe que em diversos documentos oficiais publicados após 1954, há numerosas referências ao Tietê como um elemento de contato com o interior, fixador de povoações ao longo do seu leito e condicionador de atividades econômicas no planalto do estado de São Paulo.

A formação de Barra Bonita está intimamente ligada às águas do Tietê e ao período das monções. As monções eram expedições fluviais, periódicas e sistematizadas, com objetivos 
comerciais e povoadoras que partiam do porto de Araritaguaba (atual município de Porto Feliz) rumo ao rio Cuiabá (Ohtake, 1991). A palavra monção tem origem árabe e significa época ou vento favorável à navegação. Assim, tais expedições ficaram conhecidas como monções, pois partiam nos meses de abril e maio, quando o rio apresentava condições mais adequadas à navegação e coincidia com a colheita principal de cereais em São Paulo. Durante o período de seca (junho a agosto), o rio apresentava um excesso de cachoeiras, o que dificultava o tráfego, e durante o período de chuvas (novembro a março) era perigosa a navegação devido às tempestades. Entre abril e maio era considerado o período mais adequado para a navegação, pois o leito ainda estava cheio, não apresentava tantas cachoeiras e corredeiras e as tempestades já haviam se findado (Nóbrega, 1978).

As canoas usadas para a navegação eram feitas com as técnicas indígenas adotadas pelos colonizadores com cipós e troncos de árvores como a peroba, o ximbó e o tamboril (Nóbrega, 1978). Os viajantes navegavam apenas durante o dia e descansavam à noite nas margens (Juzarte, 1769). Além disso, era costume deixar algumas pessoas em lugares escolhidos com a incumbência de formarem pequenos roçados para o abastecimento das expedições na volta; esses locais eram chamados de "barra" e indicavam as margens que pudessem dar condições de ancorar suas embarcações (Saffi et al., 1999). Barra Bonita seria, portanto, uma enseada com uma bela configuração natural, formando uma praia fluvial emoldurada por muitas espécies vegetal (Figura 1). O engenheiro Benjamim Franklin de Albuquerque Lima, chefe da Comissão de Exploração dos Rios Brasileiros, se referiu às barras como "margens bordadas de grande vegetação, onde abundam grossos madeiros e palmeiras de alto porte, sendo comum o cedro, a aroeira e a peroba" (Lima, 1877, apud Saffi et al., 1999, p.5). Assim, o rio teve papel fundamental, não só na formação do município, como também na sua denominação. 


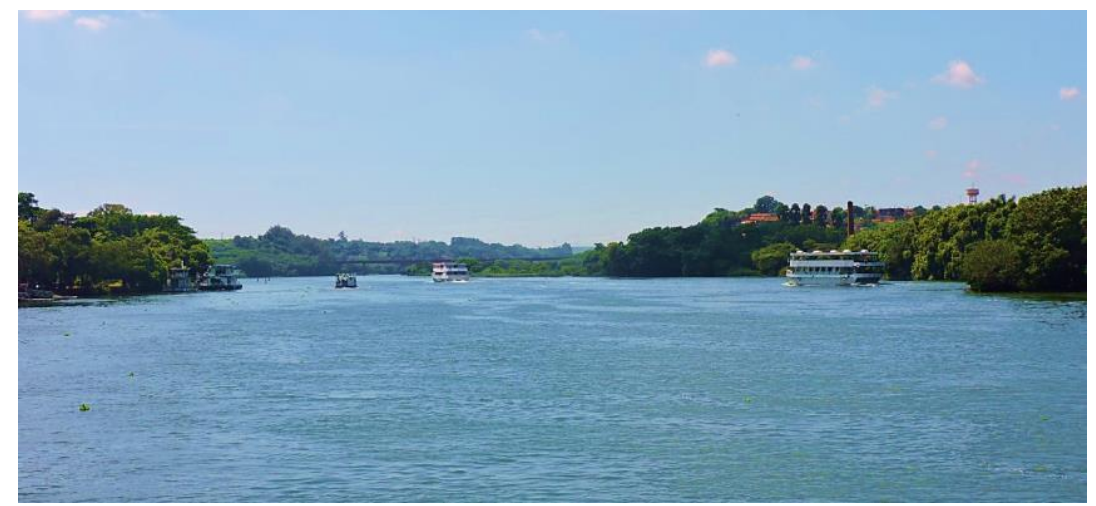

Figura 1 - Rio Tietê em Barra Bonita, São Paulo, Brasil. (Vista das embarcações turísticas que viajam pelo rio).

Fonte: Acervo dos autores

\subsection{Breve histórico de Barra Bonita}

A formação de Barra Bonita está intimamente ligada às águas do Tietê. Sua história é dividida em 4 fases, de acordo com sua relação com o Rio, sendo a primeira marcada pelas primeiras tentativas de povoamento da região a partir da expedição fluvial de 1877 - uma das várias monções em busca do ouro em Minas Gerais e Goiás (Mota; Constantino, 2017). A cidade nasceu de um antiga barra de descanso das monções e sua área inicial fazia parte da freguesia de Brotas, juntamente com as cidades de Jaú, Pederneiras, Bica de Pedra, Mineiros do Tietê e Dois Córregos. Apesar de haver muitas datas que marcam a fundação de Barra Bonita, a data considerada como oficial é a de 19 de março de 1883, fundada por José de Salles Leme (Saffi et al.,1999).

José Salles Leme era um grande fazendeiro de café e uma pessoa de grande relevo na política nacional, fundador do Partido Republicano. Em Jaú, foi vereador e presidente da Câmara Municipal (1883) e passou a adquirir grandes áreas de terras na região de Jaú e no local em que mais tarde seria fundada Barra Bonita. Financiou a construção da primeira casa de comércio, ponto de partida para a formação do município, situada na rua 1 으 de Março e esquina da rua Salvador de Toledo, estabelecendo uma sociedade mercantil com João Baptista Pompeu. Dentre suas terras, doou algumas para a construção da Igreja Matriz e a Praça São José, o Salão Paroquial e o Cemitério Municipal e vendou as demais para os moradores pioneiros (Saffi et al.,1999).

A segunda fase foi marcada pelo crescimento no setor cafeeiro associado ao fortalecimento das atividades portuárias que efetuava o transporte do café por meio da navegação no Tietê (Mota; Constantino, 2017). Tal crescimento foi responsável pela explosão populacional e 
oficialização de Barra Bonita como cidade. Em 1880, Barra Bonita recebe muitos imigrantes, principalmente italianos, mas também espanhóis, sírios e alemães. Isso levou ao aumento de tráfego de pessoas e mercadorias, o que fez com que a balsa e os barcos não atendessem mais às necessidades do intenso fluxo e, consequentemente, culminasse na implantação da ponte Campos Salles em 1915, tornando-se um marco histórico na cidade (SAFFI et al.,1999). Na década de 40, o transporte fluvial passa a ser progressivamente substituído pelo sistema rodoferroviário, sendo extinto oficialmente em 1952 (Mota; Constantino, 2017).

A terceira fase é marcada pela substituição do café pela cana-de-açúcar. Em 1943 é criada a Usina de Açúcar Barreirinho, a partir de investimento particular e, em 1949, é fundada a Usina Barra S/A Açúcar e Álcool (Mota; Constantino, 2017). O desenvolvimento industrial, após o término da Segunda Grande Guerra em 1945, fez surgir uma alta demanda por energia que levou à construção da Usina Hidrelétrica de Barra Bonita, cuja inauguração ocorreu em 1973 (Saffi et al.,1999).

A quarta e atual fase reflete no investimento do setor de turismo na cidade, o que ocasionou significativas mudanças urbanas e investimentos no rio Tietê (Mota; Constantino, 2017). Destaca-se a Hidrovia Tietê-Paraná (HTP) que foi idealizada em 1950 para o aproveitamento múltiplo das águas e ligação dos dois rios, mas somente em setembro de 1988 teve definidas as diretrizes para o planejamento, implantação, administração e operação da HTP (Silva, 2015). Nesse contexto, Barra Bonita passou a ocupar uma posição de destaque por estar próxima à HTP, o que consequentemente permitiria além do transporte de cargas, transporte de passageiros, a partir dos investimentos no turismo por parte dos governos do Estado e do Município. Atualmente o turismo foca-se principalmente em atividades relacionadas ao rio, com destaque ao passeio de barco que sai da orla do município de Barra Bonita (Figura 2). 


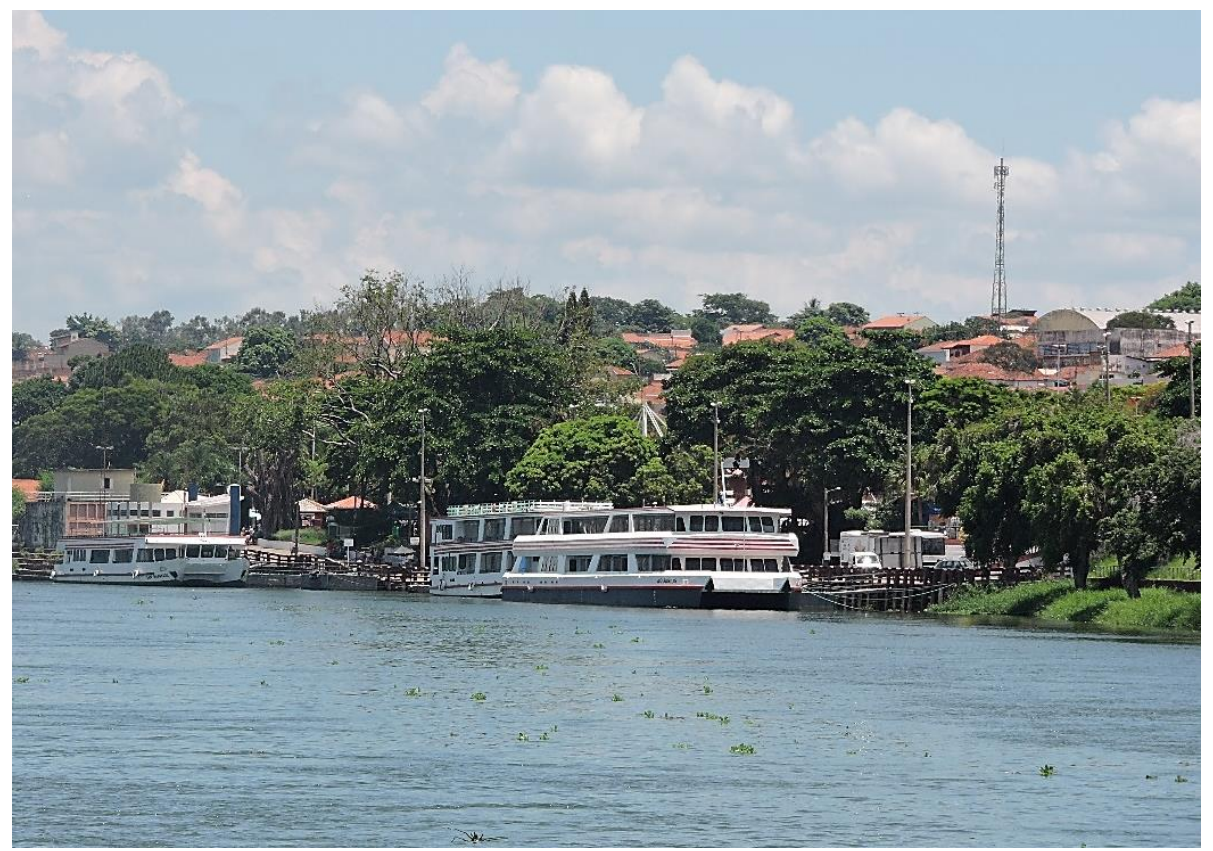

Figura 2 - Orla de Barra Bonita vista do Rio Tietê, São Paulo, Brasil. Fonte: Acervo dos autores.

\subsection{Contexto socioambiental}

Atualmente, Barra Bonita abrange uma área de $150 \mathrm{~km}^{2}$, situada a 475,59 m de altitude, e conta com uma população de 36.127 habitantes, segundo o IBGE (2018). A taxa de alfabetização, entre 6 a 14 anos, representa 99,8\%, o salário médio mensal é de 2.6 salários mínimos e a proporção de pessoas ocupadas em relação à população total é de $38,7 \%$ (Cidades IBGE, 2018). Embora seja reconhecida como cidade turística, o turismo representa uma parte incipiente da economia do município, sendo sua principal fonte de renda a produção de açúcar e álcool. Em relação à vegetação, o município está inserido em porções do Cerrado e Mata Atlântica, embora a parte urbana se restrinja, exclusivamente, à área de Cerrado (Arroba, 2018). Contudo, a vegetação nativa é quase inexistente, sendo a paisagem dominada pela monocultura de cana-de-açúcar. Segundo representante da Companhia Fluvial Tietê-Paraná, a mata ciliar é quase ausente nas margens do rio (Penteado et.al, 2017). 
Em relação ao Programa Município VerdeAzul ${ }^{3}$, Barra Bonita está na 104o posição, de 544 municípios participantes, com a nota 49,65 (PMVA, 2019). Esse é um programa lançado em 2007 pelo Governo do Estado de São Paulo, por meio da Secretaria de Estado do Meio Ambiente, que tem por objetivo medir a eficiência da gestão ambiental e estimular e auxiliar as prefeituras paulistas na elaboração e execução de suas políticas públicas para o desenvolvimento sustentável do estado (PMVA, 2019). Na Tabela 1, estão apresentadas as notas de 0-10 para cada item considerado pelo programa, bem como sua posição por categoria em relação às 544 cidades.

Com base na tabela 1, é possível perceber que a cidade se encontra apenas quatro posições depois das 100 cidades com melhores notas no ranking das diretivas propostas pelo programa. Apesar desse resultado, Barra Bonita tem muito a aprimorar em vários quesitos, principalmente, por ser considerada uma cidade turística. E no que diz respeito a os cuidados com Biodiversidade, Arborização Urbana, Sustentabilidade e Esgoto Tratado, o município precisa fazer mais investimentos, uma vez que esses índices estão com as piores notas (todas abaixo de 5) e, consequentemente, em piores posições no ranking. A qualidade das águas e a arborização urbana deveriam ser itens prioritários na cidade, tanto pela melhoria da qualidade de vida de sua população quanto pelo potencial turístico e recreativo que as águas fluviais podem oferecer.

Tabela 1 - Notas de 0-10 para cada diretiva do Programa Município Verde Azul, com suas respectivas posições em relação aos demais municípios no ano de 2019.

\begin{tabular}{|c|c|c|}
\hline DIRETIVAS & 2019 & $\begin{array}{l}\text { RANKING POR } \\
\text { CATEGORIA }\end{array}$ \\
\hline Arborização Urbana & 2.47 & 113음 \\
\hline Biodiversidade & 3.08 & 1470 \\
\hline Conselho Ambiental & 7.00 & 280 \\
\hline Esgoto Tratado & 4.96 & 105 은 \\
\hline Estrutura e Educação Ambiental & 6.32 & 63 \\
\hline Gestão das Águas & 5.30 & 810 \\
\hline Município Sustentável & 4.20 & 119 은 \\
\hline Qualidade do AR & 5.90 & 670 \\
\hline Resíduos Sólidos & 6.58 & 80 은 \\
\hline Uso do Solo & 3.84 & 840 \\
\hline
\end{tabular}

Fonte: Elaborado pela autora, com base nos dados do Programa Município Verde Azul (PMVA, 2019)

3 Maiores informações sobre o Programa Município VerdeAzul, consultar o site https://www.infraestruturameioambiente.sp.gov.br/verdeazuldigital/o-projeto/ 
Em relação à qualidade das águas do reservatório de Barra Bonita, segundo o Representante da Companhia Fluvial Tietê-Paraná, há alta concentração de fertilizantes e agrotóxicos no rio provenientes dos canaviais que circundam as margens e as terras drenadas por suas bacias (Penteado et al., 2017). Porém, de modo geral, no diagnóstico da qualidade de água feito por Buzelli e Cunha-Santino (2013), nota-se que a qualidade das águas do Rio Tietê, na porção do município de Barra Bonita, está dentro dos parâmetros estabelecidos pelo CONAMA (Conselho Nacional do Meio Ambiente) ${ }^{4}$.

As autoras observaram que a maior parte dos parâmetros de análise da qualidade da água nos períodos de estiagem e metade dos parâmetros analisados nos períodos de chuva foram considerados adequados para o abastecimento e consumo humano (Classe $1^{4}$ ). Além disso, em relação aos padrões de coliformes fecais, o reservatório de Barra Bonita pode ser considerado excelente no período de estiagem e impróprio no período de chuvas (Buzelli; Cunha-Santino, 2013). Tal mudança ocorre, pois, durante as chuvas, as águas escoam pelas ruas e encanamentos da cidade levando consigo partículas de poeira, lixo e fezes animais e humanas para dentro do rio. Esse diagnóstico coincide com dados de tratamento de esgoto no município, uma vez que, segundo o Sistema Nacional de Informações sobre Saneamento (2017), apenas 20\% do esgoto de Barra Bonita é tratado. Isso pode refletir, a longo prazo, na paisagem de Barra Bonita, uma vez que esse quadro apresenta riscos à saúde da população e, também, prejudica a imagem da cidade, considerada uma estância turística.

Outro importante elemento na paisagem da cidade é a hidrelétrica de Barra Bonita. Inaugurada em 1973 para suprir a demanda por energia elétrica, a hidrelétrica promoveu intensas transformações na economia regional. O complexo hidroenergético foi construído e administrado integralmente pelo Estado até a década de 90, quando, em 1996, passou a ser concessão na multinacional AES-Tietê (Penteado et al. 2017). A eclusa tem uma bacia hidrográfica de $32.330 \mathrm{Km}^{2}$, potencial máxima de $140.760 \mathrm{Kw}$ e potencial normal de 112.400

\footnotetext{
${ }^{4}$ O Conselho estabelece no artigo 40 da resolução 357, 5 categorias principais para a classificação das águas em relação ao uso humano (BRASIL, 2005): I - Classe especial: águas destinadas: ao abastecimento para consumo humano e à preservação do equilíbrio natural das comunidades aquáticas; II - Classe 1: águas que podem ser destinadas: ao abastecimento para consumo humano, após tratamento simplificado e à recreação de contato primário, tais como natação, esqui aquático e mergulho; III - Classe 2: águas que podem ser destinadas: ao abastecimento para consumo humano, após tratamento convencional e à recreação de contato primário, tais como natação, esqui aquático e mergulho; IV - Classe 3: águas que podem ser destinadas: a) ao abastecimento para consumo humano, após tratamento convencional ou avançado e à recreação de contato secundário; V Classe 4: águas que podem ser destinadas: à navegação e à harmonia paisagística.
} 
Kw (Petbb, 2013). Por terem sido construídas anteriormente à Resolução no 1 do CONAMA de 1986, não foram realizados estudos e relatórios de impactos ambientais para a barragem e as eclusas. Portanto, não houve estudos a respeito da biodiversidade local antes de sua construção e nem a previsão e medidas de mitigação de impactos, obrigatórios atualmente. Desse modo, não é possível saber com exatidão o que se perdeu do ponto de vista arqueológico, ambiental e cultural, uma vez que nessa época não havia leis que se preocupavam com essas questões.

Porém, analisando a paisagem atual, é possível pontuar alguns aspectos como a presença de assoreamento em muitas partes do rio, a inundação de outras áreas que antes não eram fluviais e de erosão do solo no entorno. Além disso, há algumas ocupações irregulares próximas às margens que se encontram desmatadas. Numa pesquisa feita por Penteado et al. (2017), foram realizados levantamentos dos impactos socioambientais gerados: comprometimento da produção ceramista; inundação de várzeas; desequilíbrio no aporte hídrico; ocupações irregulares; assoreamento; e desmatamento.

\subsection{Análise do entorno do Rio}

A partir da análise do mapeamento do território do município de Barra Bonita, realizado com o uso do SIG, constatou-se que a agricultura mostra-se como a principal modeladora da paisagem (representando $78,7 \%$ do município), sendo esta quase exclusivamente composta por cana-de-açúcar. Em relação às demais classes, percebe-se que a representatividade delas é muito semelhante. Isso indica também que a água é um importante elemento na paisagem, pois os rios e o urbano têm representatividade muito similar na paisagem (6,9\% e 7,4\%, respectivamente). Se considerarmos apenas os limites da área urbana, é possível perceber isso mais claramente, pois as águas banham a cidade. Na Figura 3 está representado o mapa do município, resultado da análise de uso e ocupação do solo, feito no ArcGIS. Nela, estão presentes as classes dominantes na paisagem: agricultura e vegetação herbácea (78,7\% do município), urbano $(7,4 \%)$, fragmentos de vegetação nativa (7\%) e água $(6,9 \%)$. 
Outro ponto a observar é que a maioria dos rios, seja na parte urbana ou na parte rural, não conta com os 30m de APP (Áreas de Proteção Permanente) de mata ciliar, estabelecidos pelo Art. 40 do Novo Código Florestal (Brasil, 2012). A Figura 4 apresenta um recorte na área urbana, onde estão destacados os cursos d'águas e fragmentos florestais, evidenciando a importância desses elementos na paisagem, se comparado exclusivamente com o urbano e mostrando as delimitações do que deveria ser a APP. Além disso, as fotografias ao lado do mapa evidenciam as áreas em que há ausência de mata ciliar, demonstrando a necessidade de reflorestamento nessas áreas.

Em relação ao uso do solo em Barra Bonita, o rio é margeado por muitas praças. São elas: Minicidade, Praça Doutor Tatinho, Praça da Igreja Matriz, Praça da Juventude, Praça da Marinha, Praça do Artesanato, Praça do Idoso, Praça do Teleférico e Praça dos Namorados. De modo geral, elas apresentam grande movimento aos finais de semana, quando pessoas de todas as idades circulam pelas margens do rio. Além disso, há muitos restaurantes, lanchonetes e barraquinhas de artesanato ao redor, o que pode ser considerado um fator de atratividade. Na Figura 5 estão assinaladas as principais praças do município com suas respectivas fotos.

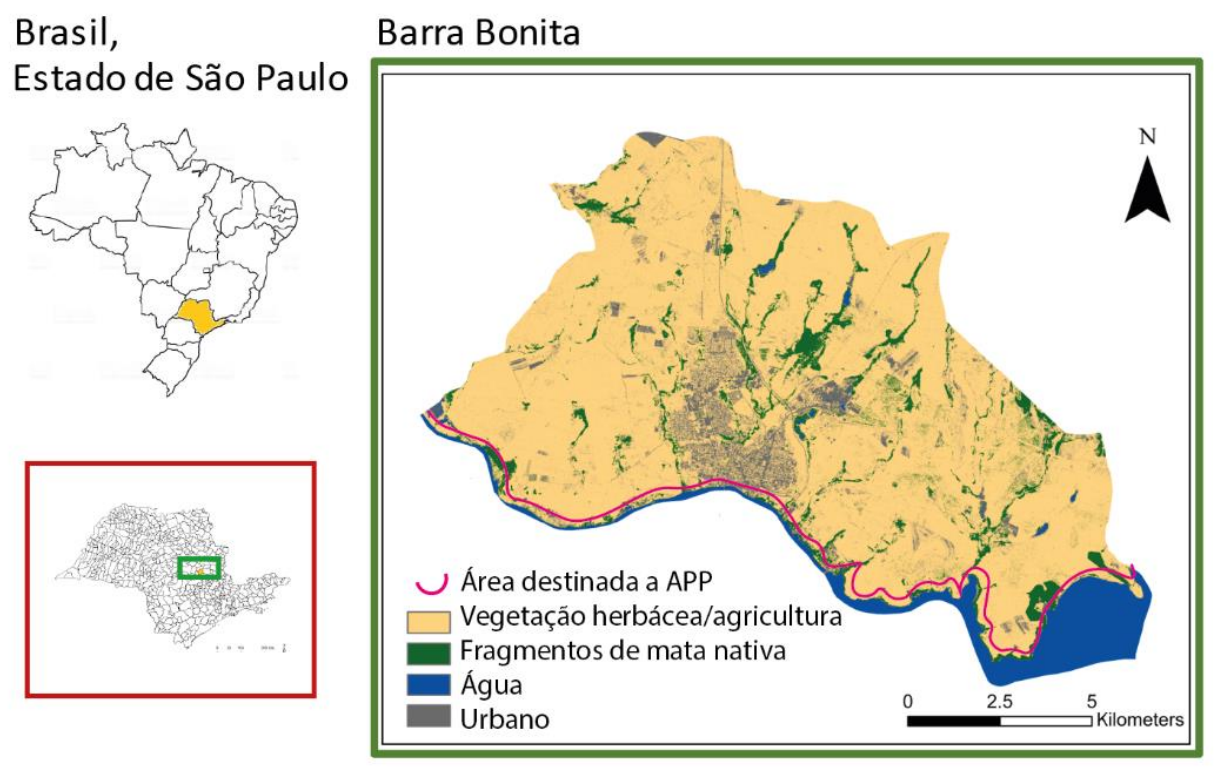

Figura 3 - O mapa do município de Barra Bonita, São Paulo, Brasil que representa as 4 classes principais de cobertura de solo presentes na paisagem. No caso a vegetação herbácea representa tanto os gramados de jardins e praças, quanto pastos e a agricultura. 
Fonte: mapa elaborado pela autora com o uso de imagens do satélite RapidEye de $25 \mathrm{~km}^{2}$, ano de 2015, com resolução espacial de $5 \mathrm{~m}$ e com 5 bandas espectrais, disponíveis no catálogo on-line do Ministério do Meio Ambiente do Brasil.
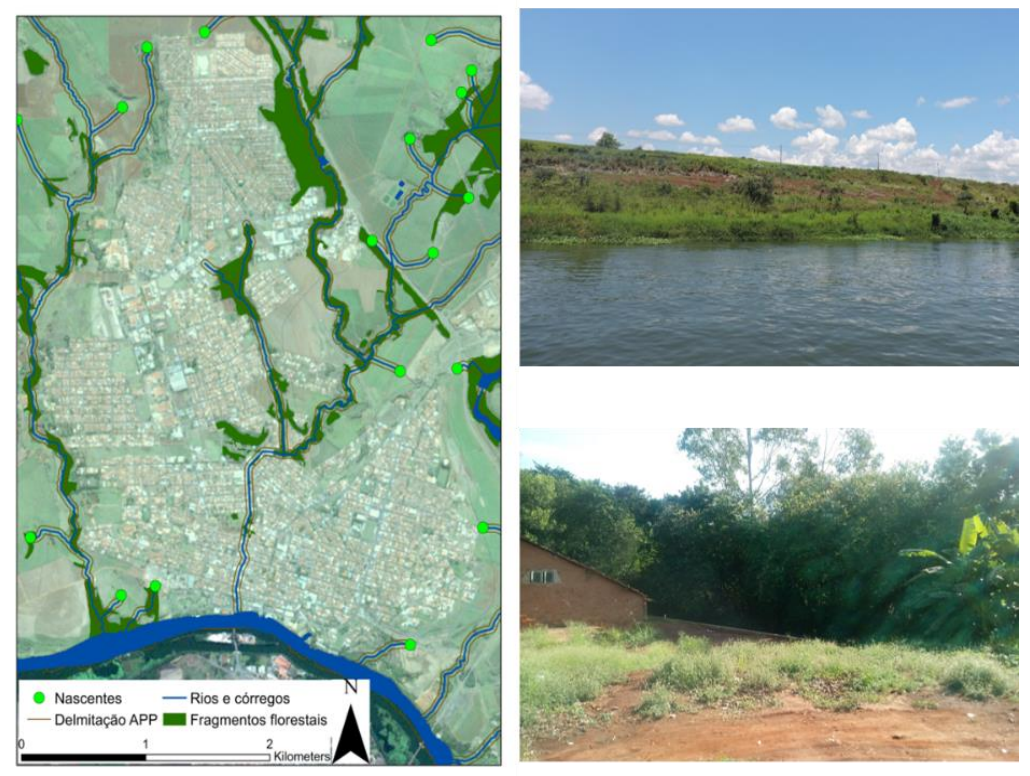

Figura 4 - No mapa, as nascentes, rios, córregos e fragmentos florestais estão destacados na parte urbana do município de Barra Bonita-SP, Brasil. Ao lado, imagens das margens do rio nos arredores do município.

Fonte: fotos de autoria própria e mapa elaborado pela autora com o uso de imagens do satélite RapidEye de $25 \mathrm{~km}^{2}$, ano de 2015, com resolução espacial de $5 \mathrm{~m}$ e com 5 bandas espectrais, disponíveis no catálogo on-line do Ministério do Meio Ambiente do Brasil.
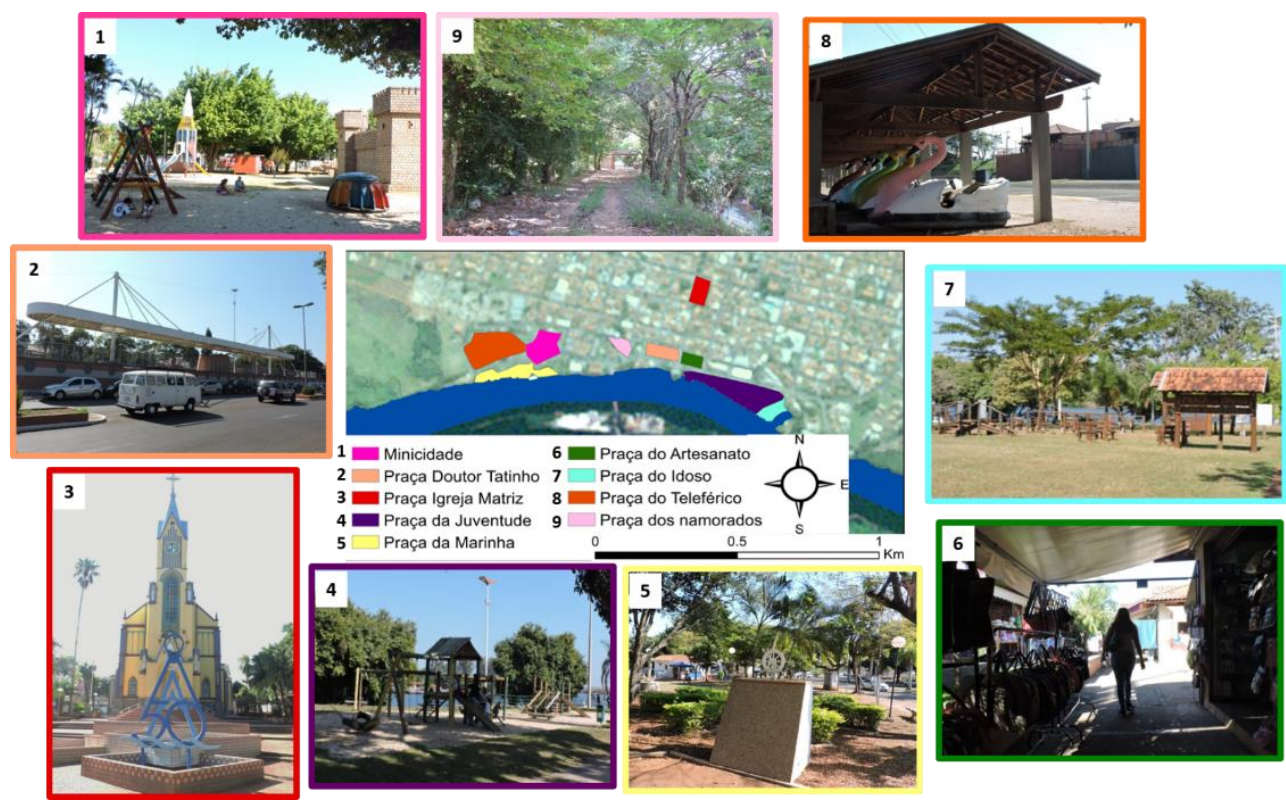

Figura 5 - Mapa com destaque para as principais praças da cidade e suas respectivas fotos. Cada borda colorida representa uma praça, cuja legenda está no mapa.

Fonte: Elaborado pela autora sobre a imagem de satélite fornecida pelo RapidEye (http://geocatalogo.mma.gov.br/). 
As praças são elementos muito importantes na paisagem de Barra Bonita pois exercem tanto função estética, quanto a função de uso para comércio e convívio social. A sua presença colabora para a melhor qualidade de vida dos moradores e visitantes (Garcia; Gulinelli, 2017). A Praça da Juventude e a Praça do Idoso permanecem bem cuidadas, tendo apenas a tintura das quadras e pistas de skate um pouco desgastadas. Nelas, muitas pessoas caminham, correm e fazem exercícios. Durante as visitas de campo, as quadras estavam sempre cheias e havia jovens sentados na grama, famílias passeando nas margens e pessoas fazendo piquenique. A Praça do Idoso era usada por pessoas de diferentes faixas etárias. As praças Minicidade, Praça Doutor Tatinho, Praça da Marinha, Praça do Teleférico e Praça dos Namorados se encontram em ótimo estado e com um alto fluxo de usuários, principalmente aos finais de semana e feriados. Na Praça do Artesanato, porém há muitas barraquinhas de venda, mas poucas são de fato de artesanato local. Apesar de haver muitos bordados e objetos feitos por artesãos, boa parte dos produtos são de origem importada.

\subsection{Percepção do Rio Tietê pelos usuários}

Atualmente, conforme já observado, Barra Bonita tem uma população estimada de 36.127 habitantes (Ibge, 2018). Desse total, 28.904 tem mais do que 15 anos de idade. Ao todo foram aplicados 270 questionários aos usuários de Barra Bonita, dos quais 34 eram turistas e 236 moradores. Em relação ao gênero, foram entrevistados 139 mulheres (51,5\%) e 131 homens (48,5\%). Em relação à faixa etária foram entrevistadas 34 pessoas com mais de 60 anos (12,6\%), 137 pessoas entre 30 e 59 (50,8\%) e 99 pessoas entre 15 e 29 anos (36,6\%)

Como resultado, vimos que $94,8 \%$ dos usuários consideram o Rio Tietê como uma opção interessante de lazer, $99,6 \%$ o consideram como uma parte importante da cidade e $87,8 \%$ dos usuários declararam saber que o Rio teve importância para a história da fundação do município. Contudo, apenas 59,3\% (160 pessoas) dos usuários declararam ter algum vínculo afetivo com o rio. Entre eles, 156 explicitaram os seus motivos que foram agrupados em oito categorias principais: infância; contemplação/vínculo espiritual; sentimentos bons; pertencimento/história da cidade; trabalho; turismo; barco; e pesca (figura 6). Em primeiro lugar, a justificativa mais mencionada para esse vínculo foi a memória da infância. Nesse 
sentido, 52 entrevistados relataram que quando crianças passaram bons momentos em sua orla ou navegando no rio. Muitos ainda contaram que aprenderam a nadar no rio e têm uma memória de vivência de adolescência e infância, cujo cenário se passa no Rio Tietê. Em segundo lugar, o vínculo foi justificado por despertar sensações boas como alegria, amor, paz, felicidade e amor pela natureza. Em terceiro lugar, o vínculo está atrelado ao trabalho, onde 20 pessoas justificaram seu afeto pelo rio porque trabalham nele diretamente ou porque a renda está vinculada a alguma atividade relacionada ao seu turismo. Em quarto lugar, 17 pessoas justificaram seus vínculos devido à contemplação e/ou aspectos espirituais como um local para meditação ou para recarregar as energias.

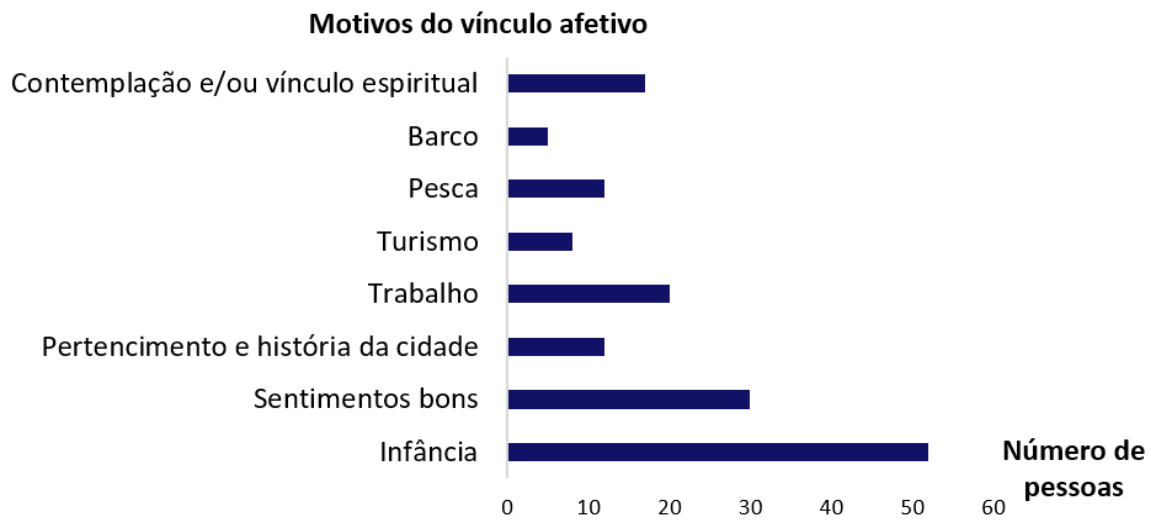

Figura 6 - Oito categorias dos motivos que levaram ao vínculo afetivo com Rio Tietê de acordo com o número de pessoas, município de Barra Bonita-SP, Brasil.

Fonte: Elaboração Própria

Em relação às atividades de lazer na cidade, foram consideradas apenas as respostas dos moradores (236 usuários não-turistas), no sentido de compreender se o rio fazia parte do cotidiano dessas pessoas. O resultado (Figura 7) mostrou, que não apenas o rio faz parte, como é a opção de lazer mais assinalada pela população de Barra Bonita. Dentre os 236 moradores entrevistados, 169 (71,6\%) pessoas declararam que passeiam na orla do rio e $145(61,4 \%)$ que utilizam as praças e parques públicos do município como forma de lazer.

Em relação ao perfil dos usuários, observou-se que o rio e os espaços públicos são bem usufruídos, independentemente da faixa etária. A proporção de usuários por idade é muito bem distribuída, encontrando pessoas de todas as faixas etárias e classes sociais frequentando as praças e a orla do rio. Dentre os usuários que passeiam na orla do rio, $40 \%$ são adultos, $30 \%$ são jovens e $30 \%$ são idosos. Dentre os usuários que utilizam praças e 
espaços públicos, $36 \%$ são jovens, 35\% são adultos e $29 \%$ são idosos. Na Figura 8 é possível perceber essa equidade na distribuição de acordo com a faixa etária tanto no caso do

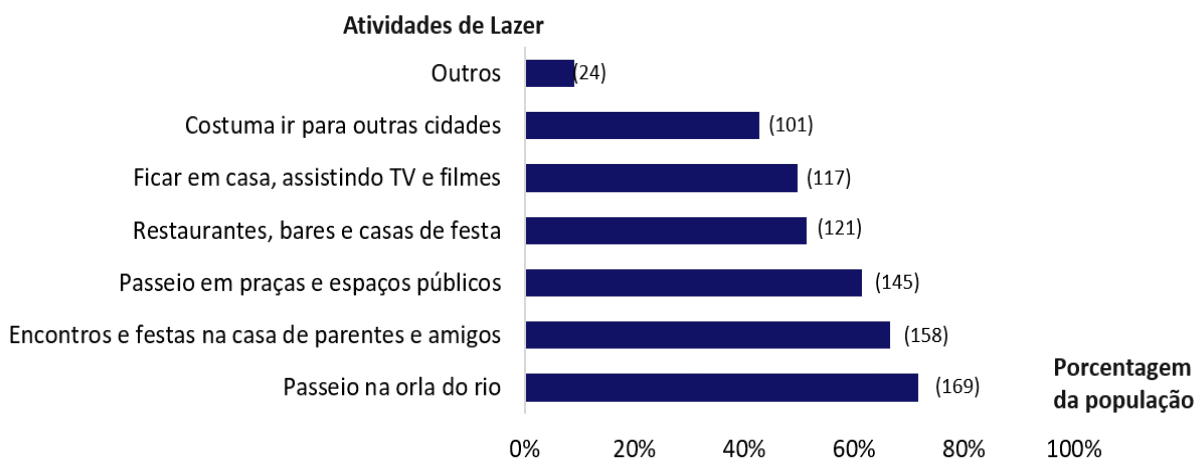

passeio na orla do rio, quanto em relação ao uso de praças e espaços públicos

Figura 7 - Atividades de lazer praticadas pela população de Barra Bonita-SP, Brasil Fonte: Elaboração Própria

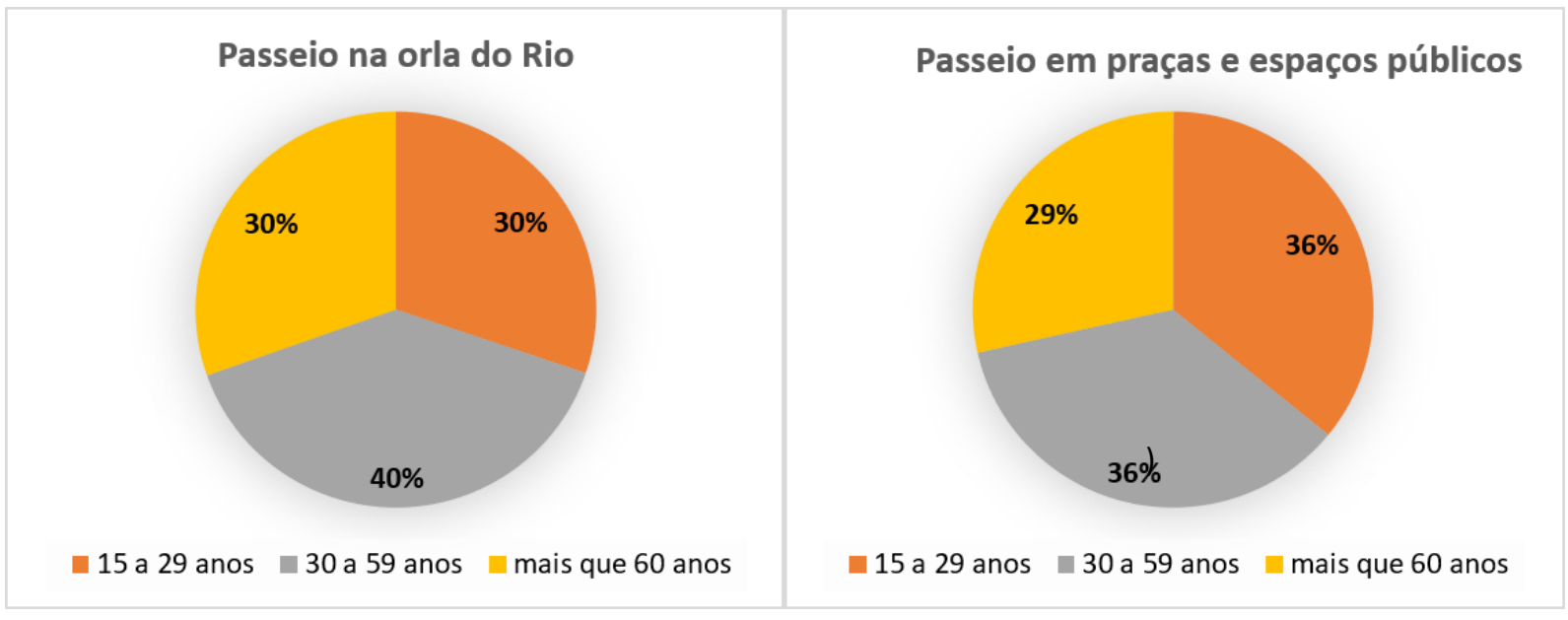

Figura 8 - Perfil etário da população que frequenta as praças e espaços públicos e a orla do rio, Barra Bonita, São Paulo, Brasil.

Fonte: Elaboração Própria

Em relação às melhorias a serem feitas (Figura 9), foram consideradas as opiniões dos 270 usuários entrevistados. Desse total, o tratamento das águas do rio foi apontado pela maioria $(77,4 \%)$ e a educação ambiental para conscientização popular foi o segundo item mais apontado pela população (76,3\%). Em relação ao tratamento de esgoto, alguns entrevistados mencionaram que não assinalaram essa opção pois está em andamento a construção da Estação de Tratamento de Esgoto de Barra Bonita. 


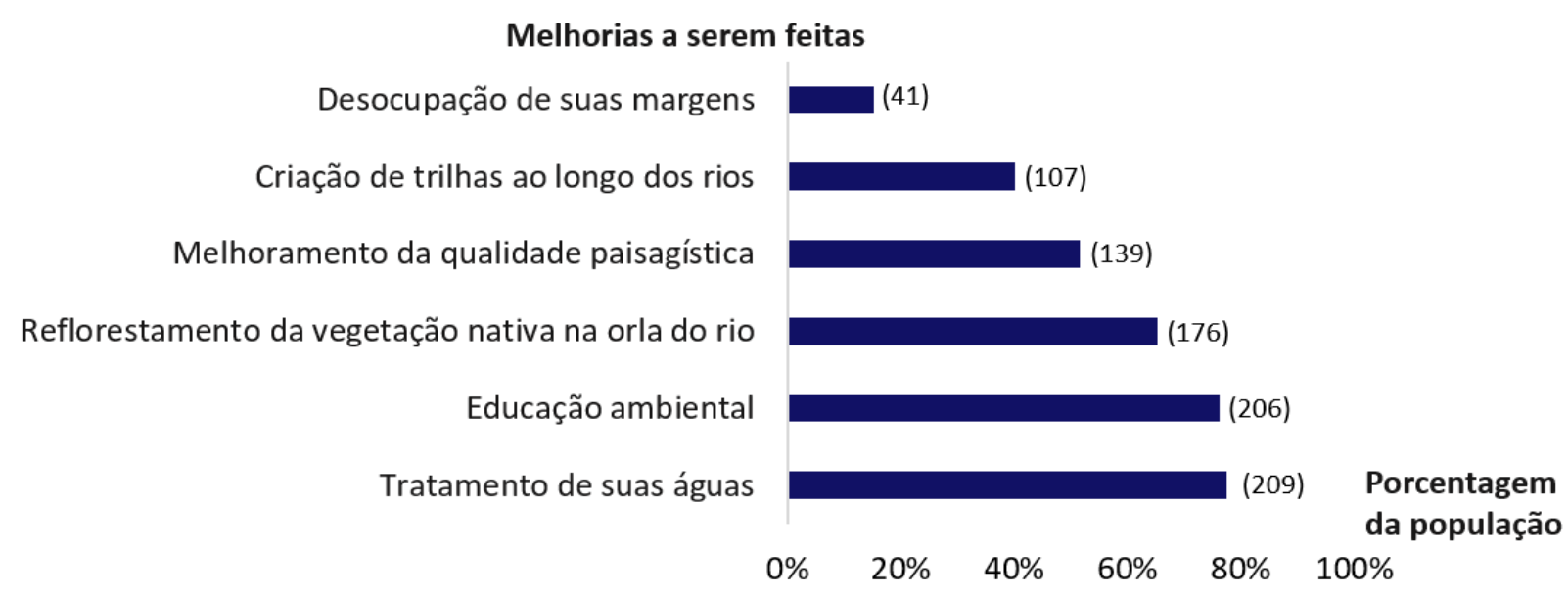

Figura 9 - Gráfico das melhorias a serem feitas no rio e em suas margens, de acordo com a porcentagem dos entrevistados na cidade de Barra Bonita-SP, Brasil.

Fonte: Elaboração Própria

Já em relação aos usos a serem usufruídos no futuro, a maioria dos entrevistados (54\%) apontou a vontade de usar o rio para nadar, como já foi no passado. Em segundo lugar, foi apontado o desejo de praticar outros esportes aquáticos $(45,2 \%)$ que promovam o contato direto com a água. Atualmente, os esportes aquáticos praticados no rio estão ligados à navegação. Embora o rio não esteja com condições apropriadas para o nado, durante as visitas de campo, foram observados adolescentes entre 12 a 18 anos entrando na água nos dias quentes. Além disso, 13 entrevistados manifestaram o desejo da volta da pesca esportiva. Essas pessoas (com mais de 50 anos) costumavam pescar durante a infância e adolescência, mas que por conta da poluição do rio deixaram tal prática. Na Figura 10, observa-se a lista dos usos a serem usufruídos de acordo com a porcentagem da população.

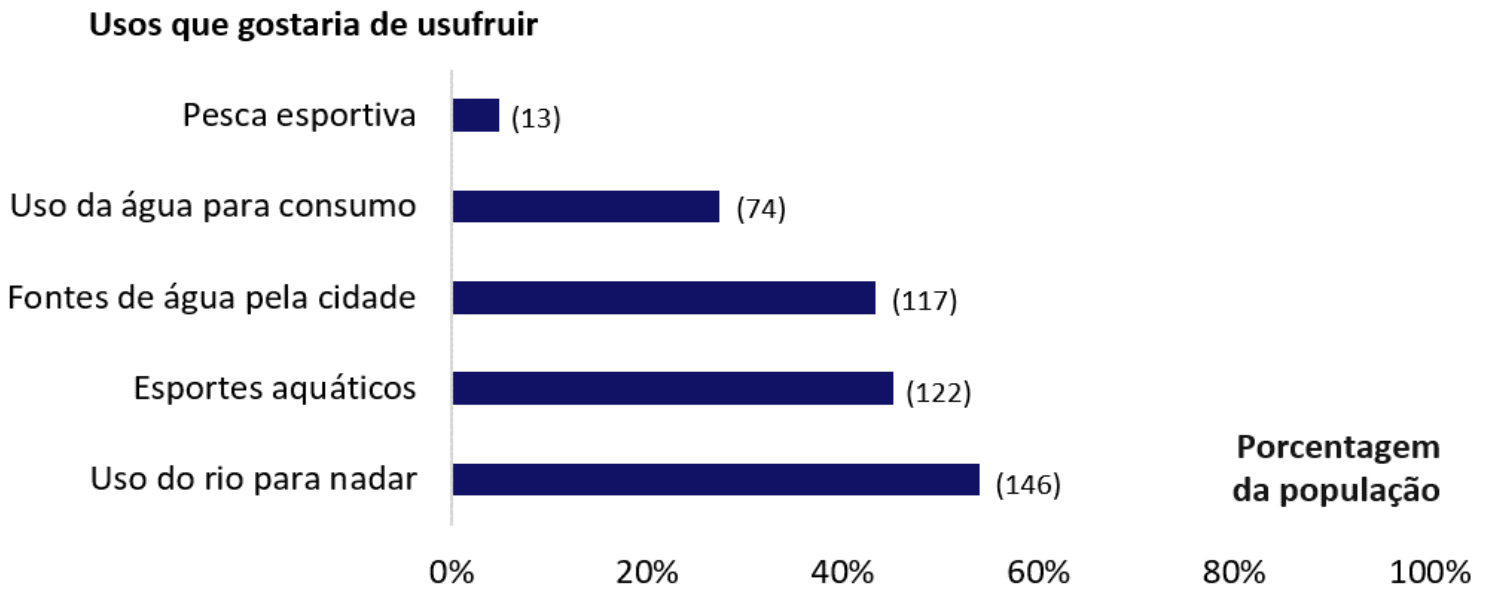


Figura 10 - Gráfico dos usos a ser usufruídono rio, de acordo com a porcentagem da população de Barra Bonita-SP, Brasil.

Fonte: Elaboração Própria

\section{Discussão}

A partir dos resultados, constatou-se que o Rio Tietê é um elemento muito importante na paisagem da cidade de Barra Bonita e que a população ainda mantém um vínculo muito forte com o Rio, seja pela memória afetiva, seja pelo trabalho ou turismo. Como o município é banhado pelo Rio Tietê e seus córregos, esta paisagem apresenta múltiplas funções e muitas formas de serem analisadas, segundo as categorias definidas por Besse (2014) e Meinig (1979). A partir do histórico do Rio Tietê e de Barra Bonita, foi possível perceber como o rio representou um importante elemento na paisagem do ponto de vista estético e estratégico (Meinig, 1979), uma vez que determinou o ponto de parada dos navegadores das monções no local onde posteriormente seria fundada a cidade. É também possível compreendê-lo do ponto de vista de representação cultural e social e de território produzido pelas sociedades ao longo da história (Besse, 2014), pois seu uso foi frequentemente transformado, de acordo com os interesses sociais e culturais da época. Como parte desse processo, podemos citar as navegações da época colonial, a criação do porto, a implantação da Hidrovia Tietê-Paraná e a criação da hidrelétrica. Esta última adicionou ao rio a função de geração de energia e transformou, drasticamente, o modo como este estava inserido na paisagem, seja pela mudança do seu curso d'água, seja por inundar áreas, causando impactos ao meio ambiente e à vida da população ribeirinha.

Também podemos analisá-lo do ponto de vista de um complexo sistêmico (Besse, 2014) uma vez que o rio é um elemento na paisagem que pode representar tanto um ecossistema em si, quanto um corredor que conecta os fragmentos de vegetação, permitindo a movimentação da fauna e flora na paisagem. Tais características irão refletir na qualidade das águas e na relação com a população. Desse modo, a paisagem pode ser entendida como uma experiência fenomenológica (Besse, 2014), uma vez que cada indivíduo percebe o rio na paisagem de acordo com sua memória e sua vivência pessoal.

A análise da integração entre rio e cidade deve considerar as variáveis ligadas à cidade, as variáveis ligadas ao rio, mas principalmente as variáveis que explicam a relação entre ambos (Silva et al. 2006). No caso de Barra Bonita, o histórico do Rio Tietê e do município foi 
importante para compreender a transformação da paisagem fluvial e sua relação com as pessoas ao longo do tempo. O contexto socioambiental trouxe um panorama geral do município e seu território, da população e da composição da paisagem, fundamental para nortear as diretrizes. Porém, dado que se trata de uma paisagem fluvial, é essencial analisar a qualidade da água e observar como estão inseridas as questões de saneamento básico no município. Também é um fator relevante a compreensão de como a hidrelétrica se insere na sociedade e quais conflitos ela gerou. A análise do estado e do uso das praças ao longo da orla fluvial trouxe a dimensão do que já existe na cidade e como estes espaços públicos são tratados pela administração municipal. Por último, os questionários possibilitaram acessar a memória da população em relação ao rio e perceber como ambos se relacionam.

Esses vários olhares sobre a paisagem são muito importantes quando analisamos como o Rio Tietê se encontra inserido na paisagem urbana, pois embora a população considere o rio como parte essencial da cidade e tenha um vínculo afetivo muito forte, há muito ainda a ser aperfeiçoado e explorado, principalmente considerando o contexto socioambiental. A expansão do tratamento de esgoto de $20 \%$ para $100 \%$ é uma medida emergencial que está em fase de andamento e construção. Com a estação de tratamento em funcionamento, muitos outros aspectos poderão ser aperfeiçoados como o uso do rio para nadar, além dos esportes aquáticos. Considerando o potencial turístico da cidade, com a inclusão desses novos usos, será possível explorar novas formas de turismo e consequentemente impulsionar a economia da cidade. Do mesmo modo, é necessária a criação de infraestrutura compatível ao turismo, como a implantação de hotéis, campings, bares e restaurantes, atraindo novos visitantes.

Em relação às áreas de APP (Áreas de Proteção Permanente), sua restauração e reflorestamento com espécies nativas são de fundamental importância para evitar os processos de erosão e assoreamento e também para filtrar poluentes e, consequentemente, melhorar a qualidade das águas (Penteado, et al. 2017). Além disso, tais áreas poderiam ser pensadas como infraestrutura verde, conciliando espaços de contato social com a natureza, mas também a criação de corredores ecológicos que conectem fragmentos e elementos na paisagem. Ribeiro e Barão (2006) viram que a implantação de corredores ecológicos permite não só aperfeiçoar a paisagem, como também a criação de novas oportunidades de lazer e descanso. Tanto em Portugal, quanto no Brasil, há vários 
exemplos de corredores criados a partir de estudos prévios da paisagem (Frischenbruder; Pellegrino, 2018; Silva et al. 2006; Ribeiro; Barão, 2006). A criação de corredores ecológicos chega como um desafio para a arquitetura paisagista, que

[...] trabalha no terreno e procura frequentemente renaturalizar, para devolver às paisagens empobrecidas e degradadas a capacidade de se desenvolverem novamente por si, retomando os processos de crescimento e de autorregeneração imanentes de que foram privadas. (Serrão, 2013, p. 24)

No caso das cidades brasileiras, o sucesso dos corredores, no aspecto ambiental e social, depende de diretrizes baseadas em exemplos de experiências de sucesso em sua implementação (Frischenbruder; Pellegrino, 2018). Para isso é necessário que o país invista em saneamento básico, tratamento de $100 \%$ de esgoto, cumprimento das leis ambientais e incentivo ao uso de espaços livres. Tais medidas trariam um novo aspecto e ajudariam a melhorar a posição do município em relação ao Programa Município VerdeAzul, o que poderia propiciar futuramente, o recebimento de bônus e novas verbas do Programa, destinadas à melhoria da paisagem.

Além disso, é possível aprimorar sua relação da interação da população com o Rio Tietê, trazendo opções de contato com a água para a população urbana, seja por meio das fontes, seja pela criação futura de decks e piscinas naturais que atraiam as pessoas a se aproximarem das águas. Para ativar todo o potencial dos corredores, é necessário: 1) produzir informação científica de qualidade e aplicá-la como ferramenta de planejamento; 2) treinar os planejadores e designers em todos os níveis para que eles levem em consideração tais estudos; e 3) compartilhar as informações científicas com todos os setores da sociedade (Frischenbruder; Pellegrino, 2018).

\section{Conclusão}

Esse artigo se propôs a analisar como o Rio Tietê se encontra inserido na paisagem urbana de Barra Bonita. O Rio Tietê foi fundamental na formação da cidade, estando inserido do ponto de vista da paisagem como processo histórico e como representação cultural, já que o rio foi o modelador essencial para a formação da Hidrovia Tietê-Paraná e a Hidrelétrica de Barra Bonita. Do ponto de vista estético, o rio tem fundamental importância, pois é um 
atrativo turístico para navegação e contemplação. Do ponto de vista sistêmico, seu potencial é pouco explorado, pois, na maior parte de suas margens, não há mata ciliar e apresenta solo degradado. Já do ponto de vista fenomenológico, podemos citar a experiência relativa à memória de pessoas que viram a formação da cidade ou que estabeleceram vínculos com suas águas. Mas em relação ao contato com as águas do rio diretamente, muito há de ser explorado, pois diversos bairros se encontram isolados e sem um contato benéfico que viria estimular a interação entre o rio e a população. Pensar na gestão das águas fluviais é essencial para superar os desafios que a urbanização vem trazendo.

\section{Referências:}

Anelli, R.L.S Uma nova cidade para as águas urbanas. Estudos avançados 29 (84), 2015. (DOI: 10.1590/S010340142015000200005)

Arroba. Cerrado Paulista, 2017. Disponível em: <http://arroba.com.br/cerrado-paulista/> Acesso em 06 de junho de 2018

Benjamin, W. Magia e técnica, arte e política: ensaios sobre literatura e história da cultura. São Paulo: Brasiliense, Obras escolhidas, v. 1, 2012

Besse, J.M. As cinco portas da paisagem - ensaio de uma cartografia das problemáticas paisagísticas contemporâneas. In: BESSE, J.M. O gosto do mundo: exercícios de paisagem. Rio de Janeiro: EDUERJ, 2014. p.11-66

Besse, J.M. Estar na paisagem, habitar, caminhar. In: CARDOSO, I.L. Paisagem e Patrimônio, Lisboa, Dafne, 2013

Borges, J. História do Rio. Navegação Fluvial Médio Tietê, 2017 Disponível em: <http://www.riotiete.com.br/historia.html> Acesso em 15 de outubro de 2017.

Brasil. Ministério do Meio Ambiente. Conselho Nacional do Meio Ambiente - CONAMA. Resolução 357. Brasília, 2005. 23p. Disponível em: <http://www.mma.gov.br/port/conama/res/res05/res35705.pdf>. Acesso em: 28 de maio de 2018.

Brasil. Lei no 12.651, de 25 de maio de 2012. Novo Código Florestal. Dispõe sobre a proteção da vegetação nativa. Diário Oficial [da] República Federativa do Brasil, Brasília, DF, 25 maio 2012. Disponível em: <http://www.planalto.gov.br/ccivil_03/_ato2011-2014/2012/lei//12651.htm> Acesso em 5 de junho de 18

Buzelli, G. M.; Cunha-Santino, M. B. Análise e diagnóstico da qualidade da água e estado trófico do reservatório de Barra Bonita (SP).Ambi-Agua, Taubaté, v. 8 (1), 2013, p. 186-205. (http://dx.doi.org/10.4136/ambi-agua.930)

Carvalho, M.C.W.; Wolff, S.F.S. Arquitetura e fotografia no Século XIX. In: Annateresa (Org.). Fotografia: Usos e Funções no Século XIX. FABRIS, São Paulo: Editora da Universidade de São Paulo, 2008.

Correâ, D.S. Os rios na formação territorial do Brasil - considerações sobre a histografia paulista. In ARRUDA, G. (org) A natureza dos rios: história, memória e territórios. Curitiba. Editora UFPR, 2008 p.47-72.

CGG - Commissão Geographica e Geológica do Estado de S. Paulo. Exploração do Rio Tietê (Barra do Rio JacaréGuassú ao Rio Paraná) - 1905. São Paulo, 3ạ Edição, 1930. 
Cidades IBGE. Brasil, São Paulo, Barra Bonita. IBGE. Disponível em: <https://cidades.ibge.gov.br/brasil/sp/barra-bonita/panorama> Acesso em 3 de junho de 2018

Correâ, D.S. Os rios na formação territorial do Brasil - considerações sobre a histografia paulista. In ARRUDA, G. (org) A natureza dos rios: história, memória e territórios. Curitiba. Editora UFPR, 2008 p.47-72.

Faber, M. A importância dos rios para as primeiras civilizações. História ilustrada, vol. 2, 2011. Disponível em: < http://www.historialivre.com/antiga/importancia_dos_rios.pdf> Acesso em 10 de outubro de 2017

Foloni, Fernanda Moço. Rios sobre o asfalto: conhecendo a paisagem para entender as enchentes, 210p.

Dissertação de Mestrado em Arquitetura e Urbanismo, Universidade Estadual Paulista. Faculdade de Arquitetura, Artes e Comunicação, Bauru, 2018.

Frischenbruder, M.T.M.; Pellegrino, P. Using green ways to reclaim nature in Brazilian cities. Landscape and Urban Planning 76, 2006, p.67-78

Garcia, N.; GULINELLI, E.L. Praças Públicas: estudos de caso das praças de Barra Bonita/SP. V Simpósio Nacional de Gerenciamento de Cidades - 3a - Semana de Arquitetura e Urbanismo da UNIVAG, Várzea Grande, MT, 2017, p. 776-790.

Goldenberg, M. A arte de pesquisar: como fazer pesquisa qualitativa em Ciências Sociais. 12a ed. Rio de Janeiro: Record, 2011.

Herzog, C.P. Cidades para todos: (re) aprendendo a conviver com a natureza. 1 ed. Rio de Janeiro: Mauad Editora/Inverde, 2013.

Herzog, C.P. A multifunctional green infrastructure design to protect and improve native biodiversity in Rio de Janeiro. Landscape Ecol Eng 12, 2016, p.141-150.

Hirota, M. \& RIBEIRO, M.Bacia do Tietê tem apenas 7\% de Mata Atlântica preservada. Fundação SOS Mata Atlântica. Blog do Planeta, publicado em 22 de setembro de 2016. Disponível em: <https://www.sosma.org.br/artigo/bacia-tiete-tem-apenas-7-de-mata-atlantica-preservada/> Acesso em 20 de agosto de 2019

Hurlbert, Stuart H. Pseudoreplication and the Design of Ecological Field Experiments. Ecological Monographs, Vol. 54, No. 2., pp. 187-211, 1984.

IBGE - INSTITUTO BRASILEIRO DE GEOGRAFIA E ESTATÍSTICA. Estimativas da população residente nos municípios brasileiro(PDF), $2017 . \quad$ Disponível em: <ftp://ftp.ibge.gov.br/Estimativas_de_Populacao/Estimativas_2017/estimativa_dou_2017.pdf> Acesso em 15 de outubro de 2017

Juzarte, T.J.Diários de Navegação,1769.In: SOUZA, J.S.; MAKINO, M. Comemoração 500 anos de Brasil. São Paulo: Edusp, 2000

Le Goff, J. História e memória. Tradução Irene Ferreira. Campinas/SP: Unicamp, 1990.

Lerner, D.N. e HOLT, A. How should we manage urban river corridors? The 18th Biennial Conference of International Society for Ecological Modelling. Procedia Environmental Sciences 13, 2012, p.721-729,

Lima, A. Relatório da Comissão de Exploração dos Rios Brasileiros, 1877 apud SAFFI, L., BOMBONATI, I. C., BOLLA, R. A., STANGHERLIN, C. 100 anos de história Barra Bonita - De Salles Leme e Pompeu (1883) a WadyMucare (1983).1999, p.5.

Magnaghi, M; Giacomozzi, S. Un fiume per il territorio: Indirizzi progettuali per il parco fluviale del Valdarno empolese. Firenze University press, 2009

Magnani, F. Inventari forestali e telerilevamento. Dispense laurea Magistrale in Progettazione e Gestione degli Ecosistemi Agro-Territoriali, Forestali e del Paesaggio, Bologna, Italia, 2015

Meinig, D.W. The Beholding Eye: Ten Versions of the Same Scene. Journal: The Interpretation of Ordinary Landscapes: Geographical Essays: 33-50, 1979.

Mello, S. Na beira do rio tem uma cidade: urbanidade e valorização dos corpos d'água. $354 \mathrm{f}$. Tese de Doutorado em Arquitetura e Urbanismo, da Faculdade de Arquitetura e Urbanismo, UnB, Brasília, 2008. 
Merleau-Ponty, M. Fenomenologia da percepção (C. Moura, Trad.). São Paulo: Martins Fontes, 1994.

Mota, V.G.; Constantino, N.R.T. Cidades e Rios no Oeste Paulista-Rio Tietê e a cidade de Barra Bonita. Revista nacional do gerenciamento das cidades 5 (23), 2017, p.27-40

Nóbrega, M. Historia do Rio Tietê. 219p. 2 ed. São Paulo: Editora Martins, 1978.

Norberg-Schulz, C. O fenômeno do lugar. In: NESBITT, K. Uma nova agenda para a arquitetura. São Paulo: CosacNaify, 2006. p.444-460.

Ohtake, R. O Livro do Tietê. 167p. Editora: Estúdio Ro, 1991.

Palmer, M.; NEAVERSON, P. Industrial Archaeology: Principles and Practice: 1. ed. Londres: Routledge, 1998, $200 \mathrm{p}$.

Penteado, C.L.C.; Almeida, D.L.; Benassi, R.F. Conflitos hídricos na gestão dos reservatórios Billings e Barra Bonita. Estudos avançados 31(89) 2017, p.299-322, Doi: 10.1590/s0103-40142017.31890023

PETBB - Prefeitura da Estância Turística de Barra Bonita. Usina hidrelétrica Barra bonita. Prefeitura da Estância Turística de Barra Bonita, 2013. Disponível em: <https://barrabonita.sp.gov.br/?page=pontosturisticos\&ver=usina-hidreletrica-barra-bonita> Acesso em: 28 de maio de 2018.

PMVA -Programa Município VerdeAzul. Ranking: pontuações, 2019. Disponível em: <http://verdeazuldigital.sp.gov.br/site/pontuacoes/> Acesso em 10 de junho de 2018

Ribeiro, L.; Barão, T.Greenways for recreation and maintenance of landscape quality: five case studies in Portugal.Landscape and Urban Planning 76, 2006, p. 79-97

Rosa, E.T.S História e memória em Serviço Social: a trajetória profissional de Nobuco Kameyama.228 f. Tese de Doutorado em Serviço Social, da Pontifícia Universidade Católica de São Paulo (PUC-SP), São Paulo, 2016.

Saffi, L., Bombonati, I. C., Bolla, R. A., Stangherlin, C. 100 anos de história Barra Bonita - De Salles Leme e Pompeu (1883) a WadyMucare (1983). Prefeitura Municipal de Barra Bonita, 1999. Disponível em: <https://barrabonita.sp.gov.br/?page=livro-100-anos-de-historia> Acesso em: 10 de mar. de 2016.

Santiago, E. Rio Tietê. Info escola: navegando e aprendendo (net), 2017. Disponível em <https://www.infoescola.com/hidrografia/rio-tiete/> Acesso em 10 de outubro de 2017

Serrão, A.V. Paisagem: natureza perdida, natureza reencontrada? Revista de Filosofia Moderna e Contemporânea, Brasília, no 2 (1), 2013, p.7-27. Disponível em: <http://www.periodicos.unb.br/index.php/fmc/ article/view>

Silva, H. Considerações sobre planejamento de eclusagens na Hidrovia Tietê-Paraná.106 f. Dissertação de Mestrado em Engenharia de Produção - Faculdade de Engenharia, UNESP, Bauru, 2015

Silva, J. B.; Serdoura, F.; Pinto, P. Urban Rivers as Factors of Urban (Dis)integration, $42^{\text {nd }}$ ISoCaRP Congress, 2006

SNIS - Sistema Nacional de Informações sobre Saneamento. Informações de Esgoto: município Barra BonitaSP, 2017. Disponível em: <http://app4.cidades.gov.br/serieHistorica/\#>Ultimo acesso em 8 de setembro de 2019

Souza, J.S.; Makino, M. Diários de Navegação - Teotônio José Juzarte. Comemoração 500 anos de Brasil. São Paulo: Edusp, 2000

Xeria, L.C. Carta do Capitão General Governador do Paraguay, Don Luis de Céspedes Xeria a Filipe IV sobre a navegação no Tietê e no Paraná, 1628. 